\title{
Comparação entre diferentes técnicas de descongelação do sêmen equino
}

Carlos Eduardo Camargo", Rodrigo Chaves Macan, Nathália Gonçalvez Cardoso, Karina Vieira Camargo, Camila Meneghini, Daniela

Portela Cardozo, Marcela Maira Miqueletto

Pontifícia Universidade Católica do Paraná (PUCPR), Curitiba, PR, Brasil

*Autor correspondente

e-mail: kaducamargo_vet@hotmail.com

\section{Resumo}

O Brasil possui o terceiro maior rebanho de equinos do mundo, tornando-se uma referência mundial pela sua criação de animais de alto desempenho bem como nas biotecnologias da reprodução de equinos. Garanhões com problemas reprodutivos são selecionados como reprodutores, desta forma, alternativas para melhorar os índices reprodutivos ao mesmo tempo melhorando a genética dos animais são alvos desejados pelos criadores, o que incentiva a utilização de biotecnologias ligadas à reprodução, como a inseminação artificial (IA) com sêmen congelado. 0 uso do sêmen congelado proporciona diversas vantagens na reprodução equina, entretanto muitas etapas como o protocolo de congelação e descongelação são fatores limitantes para o sucesso da técnica. Existe uma grande variedade de tempo e temperatura em diferentes protocolos de descongelação, sendo assim é essencial que essa etapa seja eficaz e não cause maiores danos às células espermáticas. 0 presente estudo tem por objetivo avaliar diferentes métodos para descongelação do sêmen equino, através de diferentes temperaturas e tempo de exposição ao processo que já são consagradas a campo, e comparar a uma técnica que não foi encontrada pelo nosso grupo na literatura cientifica, a qual permite um maior tempo ao médico veterinário sem causar maiores danos às células espermáticas. Para a realização desse projeto foram utilizadas palhetas de sêmen congelado de 12 (doze) garanhões comprovadamente férteis e de boa congelabilidade, armazenadas em botijão de nitrogênio líquido a $196^{\circ} \mathrm{C}$ negativos. 0 experimento foi realizado na cidade de Fazenda Rio Grande/PR, no Laboratório de Reprodução Animal da Fazenda Experimental Gralha Azul da PUCPR. Este experimento foi delineado utilizando como grupo controle dois protocolos de descongelação já consagrados a campo, grupos A e B, comparados a um grupo $\mathrm{C}$ descrito como tratamento: Grupo $\mathrm{A}, 37^{\circ} \mathrm{C}$ por 30 segundos; Grupo $\mathrm{B}, 46^{\circ} \mathrm{C}$ por 20 segundo; e Grupo $\mathrm{C}, 37^{\circ} \mathrm{C}$ por 60 segundos. Após a descongelação, foram avaliados: motilidade, vigor, morfologia espermática e integridade da membrana. Todas as amostras foram submetidas à avaliação microscópica por 
três experientes profissionais diferentes e o mesmo foi filmado por câmera acoplada ao equipamento para facilitar as análises. Toda metodologia está adotada nas linhas mestras de pesquisa em reprodução equina e normatizadas pelo Colégio Brasileiro de Reprodução Animal. Os resultados obtidos foram tabulados e avaliados seguindo preceitos de análises estatísticas segundo o método de ANOVA. Letras iguais indicam que não foi encontrada diferença estatística entre os grupos. Não foi encontrada diferença estatística (P > $0,05)$ entre os grupos controle e o grupo tratamento em nenhum dos itens avaliados. Após a descongelação dos 12 garanhões nos três grupos, A, B e C, foram obtidas as médias dos mesmos e os seguintes resultados foram obtidos referentes à motilidade espermática: 44,16\%a, 48,33\%a e 43,33\%a, respectivamente para os grupos A, B e C. No teste hiposmótico, a porcentagem de células íntegras ficou disposta da seguinte forma: 66,08\%a, 62,58\%a e 64,66\%a para os grupos A, B e C, respectivamente. Quanto à morfologia espermática, a seguinte porcentagem de células normais foi encontrada: 75,25\%a, 73,16\%a e 71,05\%a, respectivamente. Conclui-se que o sêmen congelado, quando submetido à descongelação por $37^{\circ} \mathrm{C}$ durante 60 segundos, continua viável para a inseminação artificial, sem apresentar diferença estatística em relação aos protocolos de $37^{\circ} \mathrm{C}$ durante 30 segundos e $46^{\circ} \mathrm{C}$ durante 20 segundos já consagrados a campo. A grande vantagem proposta pelo protocolo $37^{\circ} \mathrm{C}$ durante 60 segundos é proporcionar um maior tempo de descongelação, o que permite melhor preparação no laboratório e tempo hábil para realizar as técnicas necessárias com tranquilidade enquanto o sêmen é descongelado.

Palavras-chave: Sêmen. Garanhôes. Descongelação. 